\title{
GOOD EXPERIENCES FROM REUSE OF MUNICIPAL WASTEWATER, SLUDGE AND DIVERTED HUMAN URINE IN WILLOW BIOMASS PLANTATIONS - RESULTS FROM A 4-YEAR MULTIDISCIPLINARY FIELD PROJECT IN SWEDEN, FRANCE, NORTHERN IRELAND AND GREECE
}

\author{
Arne Backlund \\ $A \& B$ BACKLUND ApS, Denmark
}

\begin{abstract}
This article is based on the report "Short-rotation Willow Biomass Plantations Irrigated and Fertilised with Wastewaters" (1) and summarises results and experiences gathered from field trials with recycling of pre-treated wastewater and diverted human urine mixed with water within plantations of willow species specifically selected for biomass production. Experimental sites were established in Sweden (Roma), France (Orchies), Northern Ireland (Culmore) and Greece (Larissa). Denmark was represented in the project by A \& B BACKLUND ApS with Arne Backlund as a member of the Management Committee and as a project manager of the field trials with diverted human urine in Sweden. The research project was carried out as a co-operation between universities, institutions and private consultants from five countries during a 4-year period with financial support from the EU FAIR Programme and national funding.
\end{abstract}

\section{KEYWORDS}

Willow plantations, biomass production, wastewater treatment, soil plant filter, sludge, humane urine, ecological sanitation

\section{BACKGROUND AND PURPOSE}

Land treatment methods have been used since ancient times. At Bunslaw, Germany a sewage irrigation system commenced in 1531 and was in operation for over 300 years. Many "sewage farms" existed in the latter half of the 19th century and during the first few decades of the last century. They were replaced gradually by in-plant alternatives 
KALMAR ECO-TECH'03

Bioremediation and Leachate Treatment

KALMAR, SWEDEN, November 25-27, 2003

starting round 1920 when the activated sludge process and other biological treatment methods were introduced.

In the United States, land treatment methods in general, especially irrigation applications, have regained respect in recent years as cost-effective and competitive alternatives to conventional wastewater treatment processes in combination with recycling of wastewater nutrients. In many countries throughout the world where water resources are scarce, reclaimed wastewater is used in agriculture as a replacement for natural water supplies.

Cultivation of selected species of willows (Salix spp.) for energy purposes has rapidly increased in Sweden. About 15000 hectares of short-rotation energy forestry have been established. The total cost of chip production from willow biomass plantations by known technique amounts to $12-13$ Euro/MWh., which figure is comparable to the price of chipped residuals from conventional forestry. Further development within the area of plant breeding and cultivation technology would most likely reduce the cost of biofuels from Salix plantations.

Fertiliser costs are of great importance and correspond to $15-20 \%$ of the total chip production cost. As a complement or alternative to manufactured fertilisers recycling of waste products rich in nutrients, e.g. municipal or industrial wastewater, sewage sludge, leachate from sanitary landfills, and ashes from combustion processes, have been discussed. In Sweden there are a few full-scale facilities where willow plantations are irrigated with pre-treated wastewater. The first one began operation in 1997.

The project background has bearing on both energy and agricultural policies within the EU member states. The stated need for replacement of fossil fuels by sustainable energy sources is well documented and bio-fuels take a central position in this respect. The development of alternative crops in European agriculture is being promoted partly due to a general over-production of cereals. Energy crops are on the agenda. A third aspect is that wastewater treatment in soil-plant systems combined with reuse of wastewater resources (water, organic material and nutrients) for crop production has potentials for saving finite resources in terms of manufactured fertilisers and less use of chemicals and energy compared with traditional wastewater treatment.

Human urine only makes out about $1 \%$ of the total domestic wastewater but contains $80 \%$ / $55 \%$ of the total nitrogen and phosphorus and only $0.6 / 0.06 \%$ of the total lead and cadmium. This makes it very interesting to collect urine for willows using diverting toilet systems and waterless urinals.

The project group consisted of scientists and professionals with backgrounds in sanitation technology and wastewater and/or willow applications that saw synergetic benefits in coupling together the two disciplines. The basic expected benefits were:

- Willow plantations - as an alternative energy source - do not contribute to the increase of carbon dioxide (green house gas) in the atmosphere, as the plantations assimilate the same amount of carbon dioxide as is discharged by combustion. 
- Wastewater can supply a major part of the nutrition for the willow crop. Diverted human urine from domestic wastewater can supply nutrients in an even more balanced and clean way.

- The willow crop provides an active bio-filtration system for the wastewater's content of oxygen demanding organic material and eutrophying nutrients such as nitrogen and phosphorus.

The aims of the 4-year project, based primarily on small-scale field experiments in four countries, were evaluations of:

- The growth and biomass production of willow coppice irrigated with pre-treated wastewater and a urine mixture.

- The effectiveness in removal, from the wastewater, of biodegradable organic material and eutrophying nutrients by the soil-plant system

- The contribution of wastewater application to the overall nutrient and water requirements of the willow crop.

- Some economic, environmental, social and legal aspects of wastewater recycling in a willow-to-energy system.

\section{INVESTIGATIONS}

Willows were planted on an area of up to 5 hectares at each site with 12 - 18 plots, each $16 \mathrm{~m} \times 25 \mathrm{~m}-400 \mathrm{~m} 2$, with approximately 600 "Jorr" willow plants, for no irrigation, pure water, wastewater, human urine (Roma) and sludge (Culmore) in 3 replicates. The experimental sites were supplied with primary effluent from municipal treatment plants (Culmore and Larissa), stored industrial effluent from a chicory processing plant (Orchies), biologically treated and stored municipal wastewater (Roma) and human urine mixture from diverting low-flush toilets mixed with water (Roma). Application rates of pure water and urine mixture mixed with pure water were equal to the calculated evapotranspiration rate at each site. Wastewaters were also applied at two and three times this value to evaluate any possible negative effects.

Estimations and evaluations were carried out mainly concerning: biomass growth, potential pest and diseases of the plantations, plant water requirements, fertilisation effects of the wastewater, plant uptake of nutrients and heavy metals from applied wastewater, possible soil or groundwater impact, sanitary aspects, and potentials for removal in the soil-plant filter of nutrients and biodegradable organic material from applied wastewater.

\section{MAIN CONCLUSIONS AND RECOMMENDATIONS}

The project has resulted in a quantity of information on wastewater use and treatment in willow biomass plantations. The following conclusions and recommendations have been extracted from our findings.

- Wastewater, urine mixture or sludge could stimulate wood biomass production (willow stem growth) substantially and could replace conventional fertilisers to a 
KALMAR ECO-TECH'03

Bioremediation and Leachate Treatment

KALMAR, SWEDEN, November 25-27, 2003

large extent. In general, growth levels after a first 3-year rotation were higher compared with non-irrigated and pure water irrigated plants, as well as those reported from commercial willow plantations in Sweden.

The biomass production increased to some extent with increased wastewater application rates, especially at Larissa. This was likely a result of increased fertilisation rather than increased water supply. Plants supplied with the human urine mixture developed best and showed the highest growth. Although attacks from leaf beetles and rust were observed on some of the plantations, the effects on the biomass production seemed relatively limited. Estimated growth is shown below (Figure 1).

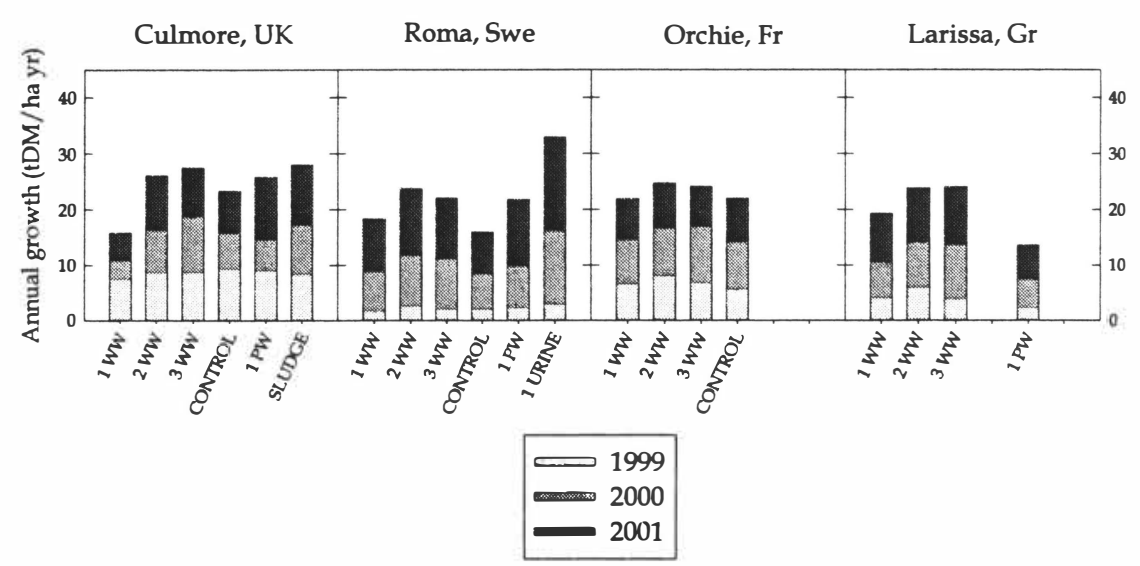

Figure 1. Estimated annual shoot growth as means of three replicates during years one to three.

The water requirement of willow plantations was assessed as being close to the theoretical potential evapotranspiration (PE) rate, independent of site location. Wastewater application up to three times the PE was proven to increase biomass growth to some extent, especially at Larissa, where the climate normally supports high evapotranspiration. However, with regard to economising with water and nutrient resources as well as minimisation of the operational costs, the total water application rates should not exceed the expected evapotranspiration rate to a considerable extent.

- The nutrient content of the wastewaters (N, P and $\mathrm{K}$ ) varied due to their origin and pre-treatment level. The primary municipal effluent at Larissa and the stored industrial effluent at Orchies were fairly well balanced but resulted in higher applications of nutrients than the total requirement. The primary municipal effluent at Culmore contained $\mathrm{N}$ and $\mathrm{K}$ amounts similar to the plant requirement but almost 10 
KALMAR ECO-TECH'03

Bioremediation and Leachate Treatment

KALMAR, SWEDEN, November 25-27, 2003

times the level of $\mathrm{P}$ required. At Roma the biologically treated and stored municipal effluent had $\mathrm{N}$ and $\mathrm{P}$ contents similar to the stem uptake, while $\mathrm{K}$ was in excess. The urine mixture contained a fairly balanced nutrient solution although the $\mathrm{P}$ content was low compared with the long-term plant requirement.

- The annual uptake of nutrients in willow stems at the different sites varied within 18$73 \mathrm{~kg} \mathrm{~N} / \mathrm{ha}$, 3-9 kg P/ha and 6-27 kg K/ha. Average P/N- and K/N-ratios of analysed stems were low at Larissa indicating that some disturbances in plant nutrition may have occurred. At Roma, $\mathrm{N}$ concentrations of stems were low, probably as a consequence of the markedly low $\mathrm{N}$ content in the applied wastewater. At Culmore, the plants seemed fairly well supplied with nutrients.

- Application of heavy metals $(\mathrm{Cu}, \mathrm{Zn}, \mathrm{Cd}$ and $\mathrm{Pb})$ with the wastewaters exceeded, in general, plant uptake rates except for $\mathrm{Zn}$ at the sites at Roma and Culmore. No obvious correlations were found between plant uptake of metals and soil or wastewater content of metals. In a long-term perspective, added metals should balance with metals removed by the crop (harvested stem wood after defoliation) in purpose to avoid accumulation of metals in the soil. Source control of applied wastewater and selection of willow clones with abilities to assimilate specific metals are possible methods of meeting the "balance criteria".

- A general pattern was that the groundwater quality was not specifically affected by the various treatments compared with the controls. At Larissa and Culmore, the concentrations of total $\mathrm{N}$ and $\mathrm{NO}_{3}$ in superficial groundwater appeared higher after low than high application rates. This was likely caused by better prerequisites for denitrification in treatments with higher hydraulic loads resulting in temporary anoxic conditions.

Metal concentrations in groundwater beneath the urine treatment were lower compared to other treatments at Roma including the control treatment. This could probably be explained by the relatively low concentrations in the applied urine mixture.

- Calculations of wastewater treatment effects using a mass balance technique over the willow-soil systems at Culmore resulted in removal rates of BOD, total $\mathrm{N}$ and total $\mathrm{P}$ within $67-74 \%, 52-75 \%$ and $90-98 \%$, respectively. In general, the highest removal rates were found in the most loaded systems. The results clearly indicate that wastewater purification of primary effluent in willow plantations could be substantial and fully comparable to tertiary effluent qualities.

A hydraulic load up to three times the evapotranspiration rate from the system did not influence wastewater treatment capacities as exemplified with data from Culmore. Thus, managing a system with wastewater irrigation according to water and nutrient requirements of a willow biomass plantation seems possible without negative environmental impacts with regard to oxygen demanding substances and eutrophying components. 
- The potential transmission routes for pathogens to animals and humans after wastewater irrigation are via aerosols (depending on the type of irrigation equipment installed), transportation via the groundwater zone to production wells or transportation via surface run off to surface waters. A general recommendation concerning elimination of the aerosol problem is to install equipment based on solidset sprinklers operating at low pressures with a short throwing distance or pipes laid on the ground and equipped with drip emitters. The risk of contamination of surface waters increases with high hydraulic loads and low soil permeability in combination with the actual slope of the terrain.

The risk of groundwater contamination primarily depends on the soil permeability and/or the distance to the saturated groundwater zone or actual production wells. In this study was found that the number of indicator microorganisms in superficial groundwater indicated a contamination risk to the groundwater at the Culmore site. Probable explanations could be that the unsaturated zone was shallow (varied between $0.5 \mathrm{~m}$ and $2.5 \mathrm{~m}$ ) and that the soil profile was relatively permeable (sandy loam). The concentration of indicators increased with the wastewater application rates.

- Economic calculations regarding willow growing in Northern Ireland show that 9 tonnes of biomass (dry matter basis) per hectare is required to achieve a positive income from the land. The outcome from a willow plantation could be competitive with grassland-based enterprises. In connection with wastewater treatment, the possibilities of reducing costs, compared to conventional nutrient removal from wastewater, is more important than the reduced costs for the farmer in savings from purchasing fertiliser.

Factors for keeping costs low in a willow bio-filter system are high concentrations and applications rates of nutrients, an extended irrigation season (since fixed costs are much higher than running costs), short pumping distances and large areas of willow plantations to be irrigated.

- Recycling of resources and production of environmentally sound biofuels are integral parts of sustainable development and thus are promoted by the political society. Nevertheless, the public acceptance of the use of wastewater, urine or sludge in willow biomass systems, as in other projects with possible environmental impact, is most important and must be treated with the same consideration as anything else in the realisation phase of a project. Any fear the public may feel has to be met with openness and confidence.

In most European countries the environmental laws include obligatory parts where any plaintiff or citizen with appropriate authority has the right of objecting before any permission or licence can be accepted and approved. In Sweden, some facilities with wastewater irrigation of willow plantations have been in operation since 1997. Before approval, the Swedish environmental authorities required the municipalities to carry 
KALMAR ECO-TECH'03

Bioremediation and Leachate Treatment

KALMAR, SWEDEN, November 25-27, 2003

out risk assessments on the possibility of infectious diseases spread, to inform the public via posters at the site, and to use ground based irrigation equipment for elimination of aerosols. No complaints from the citizens or others have been reported from the Swedish sites.

The results clearly indicated that biomass production in young willow plantations could be enhanced substantially after recycling of wastewater resources. The impact on soil and groundwater of nutrients (nitrogen and phosphorus) and heavy metals (copper, zinc, lead and cadmium) was limited, even when the application of water and nutrients exceeded the plant requirements. Also, the soil-plant system seemed to function as a natural treatment filter for pre-treated (primary settled) wastewater, with a treatment rate fully comparable to a tertiary effluent quality with regard to biodegradable organic material and eutrophying nutrients (nitrogen and phosphorus).

Introductory analyses of the costs of a wastewater irrigated willow plantation for biofuel production indicate that the benefits of the wastewater treatment per se appear to be greater than the benefits from the increased production of wood chips. The risks of contamination via faecal microorganisms of animals and humans seem possible to reduce or eliminate if proper precautions are taken.

The gathered opinion from the members of the multidisciplinary project team is that the concept of recycling wastewater or fractions of wastewater within willow plantations for combined energy production and wastewater treatment would be worth developing on a wider scale. Experiences from few full-scale facilities in Sweden are well in accordance with the findings outlined in this project. The fact that wastewater could be treated at reasonable costs might encourage the municipal sector as well as the energy and agricultural industry in Europe to further expand the concept with increased willow plantation areas as a consequence. This would increase the opportunities for an over all better environment for generations to come.

\section{REFERENCES:}

[1] Larsson, S.; Aronsson, P.; Backlund, A.; Carlander, A.; Clause P.; Cuingnet,C.; Dawson, M.; Hasselgren, K.; Jacobsson, I.; Mavrogianopoulus, G.; Perttu, K.; Riddel-Black, D.; Rosenqvist, H.; Stenstrøm, T.A.; Wilson, F.; Åmman, I.: Short-rotation Willow Biomass Plantations Irrigated and Fertilised with Wastewaters. Results from a 4-year multidisciplinary field project in Sweden, France, Northern Ireland and Greece.Sustainable Urban Renewal and Wastewater Treatment no. 38, 2003, ISBN - electronic ISBN 87-7972-744-1 